\title{
The use of process benchmarking in the water industry to introduce changes in the digitization of the company's value chain
}

\author{
Natalia R. Potoczek ${ }^{1}$
}

\begin{abstract}
PURPOSE: The review of the literature and numerous online sources, in particular the information platforms of international organizations supporting the activities of the water sector, was aimed at verifying research experiences in the field of digital maturity of enterprises, identifying research approaches used in benchmarking water utilities, and determining the level of interest in the analysis of the water supply industry value chain. It was found that there is no benchmarking methodology that would enable the observation of changes in the business processes of water supply companies under the influence of digital technologies. Therefore, this article presents a framework for benchmarking the digitization of business processes. The article also presents the premises for benchmarking the digitization of processes included in the value chain of a water supply company and the benefits of including digital technologies supporting processes from an economic, social, and environmental perspective. One of the key stages of creating the concept of benchmarking research is creating a matrix of variables relating to the objectives pursued by water supply companies. METHODOLOGY: The proposed concept of benchmarking the digitization of business processes included in the value chain of a water utility company was prepared based on literature studies and analysis of selected internet platforms of international organizations operating in the water sector. FINDINGS: The analysis of the decomposition of the enterprise value chain, the criteria, and levels of process maturity assessment, and the latest digital technologies made it possible to prepare two scenarios of the benchmarking stages of processes and use digital technologies depending on the level of process maturity and benchmarking experience. IMPLICATIONS FOR THEORY AND PRACTICE: The proposed model is highly conceptual and requires validation in pilot studies to verify the levels of decomposition of the

\footnotetext{
1 Natalia R. Potoczek, Ph.D., Hab., Professor of Institute of Economics, Polish Academy of Sciences, Laboratory of Process and Network Analysis, Nowy Swiat 72, 30-330 Warsaw, Poland, e-mail: npotoczek@inepan.waw.pl (ORCID: https://orcid.
} org/0000-0002-7288-0321).
\end{abstract}

Received 19 July 2021; Revised 7 September 2021, 23 September 2021, 29 September 2021; Accepted 30 September 2021. This is an open access article under the CC BY license (https://creativecommons.org/licenses/by/4.0/legalcode). 
value chain, to select key digital technologies for research and to determine the scale of digital maturity for each of the technologies included in the study. Organizations conducting benchmarking research can broaden the scope of their research and provide water utilities with information on the latest digital technologies supporting business processes. ORIGINALITY AND VALUE: Using value chain taxonomy to assess the support of business processes by digital technologies is an original approach. It enables the acquisition of knowledge about the importance of digital technologies in all processes carried out in the enterprise.

Keywords: value chain, process benchmarking, process maturity, digital maturity, Industry 4.0.

\section{INTRODUCTION}

Dynamic social, demographic and environmental changes pose increasing challenges in the economic sphere for every sector, industry, and enterprise. This means the need to search for new technological and organizational solutions, as well as new competences that will contribute to the optimization of production costs while promoting access for all people. Benchmarking has been a widely used method supporting the development of an enterprise since the nineties of the twentieth century.

Benchmarking as a research method is invariably used to compare the performance of processes, products, or services. The use of this method helps enterprises to overcome barriers faster and optimize costs. The method of comparing oneself with recognized or best-in-class entities is to simultaneously search for own solutions and inspire innovation. The usefulness of the method is emphasized by the latest publications by Ahmed et al. (2020), presenting research on enterprises (SMEs) in the Greater Toronto Area (GTA), as well as studies by Francisco et al. (2020) on the use of benchmarking to reduce energy consumption in cities. Benchmarking is also used to create models for cost reduction at the national level. An interesting example is the research of the National Electricity Agency (ANEEL) in Brazil, which was presented in a recent article by Lopes et al. (2020).

The analysis of the latest benchmarking research shows that benchmarking is a cross-sectoral research method, which means that it can be applied in all sectors of the economy. This is evidenced by the latest research, for example: Morse et al. (2020) dedicated to bus performance in the US; studies by Luo et al. (2020) in the Chinese construction sector; studies by Salim et al. (2020) for the comparison of Indonesia's foreign trade with Singapore and Hong Kong; studies by Williams et al. (2020) including a cost-effectiveness analysis of water retail in England and Wales; Beath and Flynn's research in the financial sector (2020) comparing the performance of private equity portfolios of the largest 
institutional investors in the world; a study by Ferreira and Marques (2021) on public-private partnerships in healthcare services in Portugal.

The benchmarking methodology is consistently improved, developed, and subject to systematic reviews. Among the latest publications, Daraio et al. (2020) works is the first attempt to systematically review all available empirical research in a wide range of efficiency and productivity analysis using the boundary estimation methodology. The research by Malik et al. (2021), which aimed to test and document a new approach to best practice benchmarking, is known as rapid benchmarking. They define rapid benchmarking as an approach to reduce drastically the typical time needed to conduct a successful best-practice benchmarking project. The latest research by Kulikowski (2021), aimed at filling the gap in the creation of theoretical models relating to human limitations in performance management, also seems valuable.

The article's main aim is to present the concept of extending benchmarking research in the water supply industry to identify digital technologies supporting business processes included in enterprise value chains. The classic research model based on key performance indicators (KPIs) indicates the possible level of improvement of the company or selected processes. However, contemporary social and environmental challenges force an increase in the pace of creating innovations and implementing modern technologies. It is assumed that the knowledge obtained from classic benchmarking studies, given the current technological challenges, does not sufficiently support the development strategies of water supply companies, which should take into account digital development. There is, therefore, a need to develop research methods to build knowledge on innovative digital technologies that make a significant contribution to improving water supply companies.

The importance of benchmarking, and at the same time its problematic nature, is strongly recognized in the water sector, especially in the water supply industry. The problem with the availability of drinking water and sewage services on a global scale is growing. Reports by international organizations, such as WHO, UNICEF, UNESCO, indicate that over 2 billion people do not have access to safely managed water services, 4.5 billion people are deprived of decent sanitary conditions, $80 \%$ of wastewater returns to the ecosystem without treatment or reuse, around 1.7 billion people live in areas where groundwater resources and / or groundwater-dependent ecosystems are under threat (WHO-UNICEF JMP 2017; World Water Development Report, UNESCO, 2017; Gleeson et al., 2012).

Given such data, it is believed that the global water sector is facing an urgent strategic change. Many international organizations and initiatives, such as the International Water Association (IWA), The International Benchmarking Network for Water and Sanitation Utilities (IBNET), and 
various regional and national organizations, have developed a cooperation network for technological, organizational, and legal development. The IWA points out that it is necessary to build an interdisciplinary environment for the development of the water sector, bringing together scientists, researchers and technology companies, as well as water and sewage companies (Strategic Plan IWA 2019-2024).

The problems in the water sector outlined above represent major challenges for the various water resource operators, entities responsible for water treatment and supply, and all users. However, the involvement of national and local decision-makers is not sufficient in all regions of the world. Many cross-sectoral organizations of cross-sector importance initiate activities to build knowledge on water resource management for various stakeholder groups, e.g. World Bank Group (IBRD - IDA) with financial support from The International Bank for Reconstruction and Development (IBRD).

In this article, the author assumed that the most important development directions in water supply companies currently include the digitization of as many operational and support processes as possible. It is assumed that new digital technologies will help to solve water problems more quickly. The technology development so far, ranging from stationary computerization of workplaces through the Internet and mobile devices, has become a lever for the development of 4.0 technologies, such as the Internet of Things, artificial intelligence, robotization, and cloud solutions. Although it has always been a priority, technological development for water companies is now becoming a challenge, forcing the rapid acquisition of new digital competencies.

The water supply industry, like any other, is created by entities that are at various stages of implementing industrial innovations. Diffusion of innovation, according to the concept of Rogers (2010), takes place in many stages and requires making many decisions: taking action to obtain information, expanding knowledge about innovation, developing one's own position on innovation, making a decision on the use of innovation, implementation, and evaluation of the usefulness of innovation, the end of confirming the usefulness of the innovation. In the era of rapidly occurring technological changes, it is also necessary to search for methods that will significantly shorten the diffusion of innovation. These include benchmarking studies, and as long as they are not limited only to the obtained indicators and compare the methods or technologies of achieving them. Observations of the changes taking place in the value chain meet the demand for system solutions relating to all organization activities. The attempt made in the article to expand benchmarking research with an analysis of the value chain, allows the identification of innovations undertaken by enterprises from the perspective of the processes implemented in the value chain that create 
a dynamic, multi-instance structure of tasks, resources, technologies, and competences. The innovations implemented by enterprises have a significant impact on the structure of the value chain.

The article presents the concept of benchmarking of business processes forming the value chain to identify, above all, innovative digital technologies and the benefits of using them in achieving higher efficiency and taking on new civilization challenges. Proposing the concept of benchmarking research in the field of digital support in processes requires, first of all, a reference to research on the digital maturity of enterprises, the nature of benchmarking research in the water supply industry, and research experience in the analysis of the value chain in the water supply industry. Hence, the presentation of the original research concept was preceded by the identification and analysis of research approaches to date. Therefore, the conducted research was aimed at answering the following questions:

$R Q$ 1: What are the research experiences in the field of digital maturity of enterprises?

$R Q$ 2: What research approaches are used in benchmarking water utilities?

$R Q$ 3: What is the level of interest in water, value chain analysis?

$R Q$ 4: What are the possible scenarios for process benchmarking research considering the use of digital technologies?

Each change made in the value chain structure is associated with a change in production costs, use of material and intangible resources, human resources and, above all, the quality of the products and services provided. Therefore, this consistency is an important premise for the development of benchmarking of digitization of the processes that make up the value chain in any enterprise.

\section{METHODOLOGICAL PROCEEDING}

The presented concept of the benchmarking study is dedicated to the water supply industry in the utility sector. When starting the new concept of the benchmarking methodology, it is assumed that benchmarking research should also provide information on the impact of the digital technologies used on the company's results. The use of digital technologies will be understood as a combination of various digital techniques (aimed at creating digital circuits and their application in digital devices) and information systems (including various hardware and software configurations) intended for information processing. In developing the benchmarking methodology, it is also 
necessary to adopt the perspective of management science, which considers economic aspects and technical, human, and organizational aspects in the use of digital technologies in business processes. It is also necessary to adopt an appropriate perspective in understanding the concepts of digitization of business processes and value chains. In each of these cases, digitization is a technological process that uses digital techniques and devices and other tangible and intangible resources of an enterprise to improve business processes and optimize manufacturing costs.

Benchmarking based on the identification and comparison of performance indicators does not give an idea of the technologies used (including digital ones) or how those technologies have changed the enterprise. The presented approach is based on the analysis of the value chain structure and digital maturity of business processes. Both issues: value chain and digital maturity of processes are discussed in detail in the next part of the article.

The concept of extending benchmarking research with applied digital technologies in the entire value chain should enable answers to the following questions: 1) Which technological innovations have led to changes in the value chain?; 2) Which changes in the value chain structure made after the implementation of technological innovations have influenced the improvement of performance and quality indicators (KPIs)?

The author developed the concept of the benchmarking study after a critical review of the literature and the identification of the research gap. Due to the practical usefulness of the benchmarking methodology, she consciously used both scientific literature and research results from specialized organizations such as WHO, IWA, IBNET, World Bank Group (IBRD IDA), EurEau. The review of the scientific literature was made primarily based on two scientific databases: Scopus and Web of Science (WoS). Other sources, mainly online, were collected according to the same keywords (tags) used in the review of scientific databases. Both literature studies and the analysis of online platforms run by the above-mentioned organizations allowed to recognize various research problems and concepts of comparative research in many sectors. The water sector was subject to detailed identification.

The research was carried out in the three stages presented below; the purpose was to answer the RQ1-RQ3 questions included in the Introduction.

Stage 1. Identification of research on the digital maturity of enterprises.

Stage 2. Identification of research approaches and methods used in benchmarking water utilities.

Stage 3. Analysis of the level of interest in analyzing the value chain in the water supply industry. 
The Scopus and Web of Science research databases were reviewed within selected research areas and without any time limits. The subject area: Business Management Accounting is included in the Scopus database. The following WoS categories were selected: Management Business Economics and Operation Research Management.

Initial identification of literature sources was carried out based on titles, keywords, and abstracts, according to the following keywords:

Stage 1: "digital maturity", "digitization", "Industry 4.0".

Stage 2: "benchmarking methodology", "benchmarking" and "utilities", "benchmarking" and "water sector".

Stage 3: "value chain analysis", "value chain" and "utilities", "value chain" and "water sector".

Finally, 32 publications in the first stage, 45 publications in the second stage and 43 publications in the third stage were selected for in-depth analysis. All selected publications were in English and the vast majority (approx. 90\%) was published in open access.

The answer to the fourth question (RQ4) concerning the scenarios of using benchmarking of digitization of processes in the value chain was included in the last part of the article. Ultimately, two benchmarking research scenarios depending on the benchmarking experience and the level of digitization were proposed. Then, presented examples of variable matrices for the analysis of digital maturity of the value chain in water supply companies. The presented concept does not contain technical and tool details. These stages of benchmarking conceptualization should be designed adequately to the scope of research: subject, subjective, temporal, and spatial.

\section{LITERATURE REVIEW}

\section{Digital transformation of value chains}

The value chain concept is a standard in economics today because it explains in a consistent and logical way the systemic structure of activities necessary to create and deliver value to the customer, which is contained in a product or service. The sets of activities included in individual elements of the first model developed by Porter (1985) were distinguished according to the functional area of the enterprise. The reference to the key functions of an enterprise in the value chain model resulted from the commonly dominant functional orientation of enterprises. Currently, functional orientation in the 
company is giving way to a process approach that has been developing for several decades, mainly due to information systems and digital technologies (Shafagatova \& Van Looy, 2021; Glavan, 2020; Christiansson \& Rentzhog, 2020; Looy, 2020; Novak \& Janeš, 2019; Ponomarenko, 2019; van Assen, 2018; Broberg et al., 2018; Miri-Lavassani \& Movahedi, 2018; Potoczek, 2017; Khosravi, 2016; Movahedi et al., 2016). The contemporary approach to the value chain primarily exposes the processes implemented in the enterprise, the organization of which resembles the structure of the Porter value chain in its basic assumption. An important component of the original model was the margin obtained by the enterprise, the amount of which reflected the level of competitiveness. Currently, the margin reflects the level of customer satisfaction, but also the results of performance management (Goni et al., 2021; Muntean, 2018; Baldwin \& Venables, 2015). The value chain concept is much more applicable today than it was in the 1980s. It is used in many sectors, and it can be used in any organization where value is created for the recipient of products or services. Thus, both the commercial and public sectors can structure their activities according to the value chain and thus have a greater impact on creating value for the customer.

The subject of many studies is the changes taking place in value chains, and the observations concern both the structure of the chain, its decomposition from processes, through sub-processes, to various activities undertaken by teams and individuals. The changes taking place in the structure of the value chain are a consequence of planned and unplanned activities. They are both the result of applying methods of improving processes, introducing innovations, expanding activities (Bustinza et al., 2015), and internal omissions or late reactions to changes in the environment, resulting in short life cycles of processes.

The last strong trend in research on value chains in enterprises is the identification of changes under the influence of digital technologies used in processes. Robotization and process automation, which was initiated in the last decades of the twentieth century, is gaining a new pace and a new quality today, thanks to the Internet, Internet of Things (IoT), artificial intelligence, cloud computing, working on large data sets, or the use of augmented reality. Analytical skills in enterprises and digital skills of employees are developed to an unprecedented extent. The impact of new digital technologies on changes in enterprise value chains, on productivity growth and economic growth, is the subject of many studies (Garzoni et al., 2020; Bickauske et al., 2020; Telnov et al., 2020; Sommarberg \& Makinen, 2019; Valdez-De-Leon, 2019; Trabucchi et al., 2018; Fonseca, 2018; Pagani \& Pardo, 2017; Graetz \& Michaels, 2018). Accelerated digitization of processes is driven by technological innovation, rapidly changing customer needs, and a variety of environmental, social, political, and health factors. 
Various studies on value chains show that the use of digital technologies has influenced the crossing of functional boundaries and affects the entire value chain in the company, and therefore all groups of processes. Many authors, such as Nagy et al. (2018), point to the evolution of value chains due to the increasingly used digital technologies. Operational processes such as production, procurement, logistics, marketing and sales, and customer service are supported by various technologies, e.g. robot automation and autonomization, RFID sensors, M2M technologies, network technologies, customer relationship management, CRM in real-time, blockchain, and the analysis of big data on customer behavior. Supporting processes are also developed using advanced technologies, e.g. ensuring data security, financial data analysis or real-time controlling, remuneration management based on current work results. For the area carrying out tasks related to human resources, the challenge is to manage the disappearing and new areas of work caused by the implementation of digital technologies. The progressive implementation of digital technologies helps to increase the flexibility and adaptability of enterprises to the environment, to cooperate with other market players, and especially to participate in shared supply chains. Digital technologies significantly accelerate the maturation of processes in organizations and increase enterprises' ability to implement processes with external partners.

The process maturity of enterprises has been the subject of many studies. Over the last two decades, there have been many proposals for methods of testing process maturity (Röglinger et al., 2012). There were also a number of studies identifying and classifying models for testing process maturity, which had the greatest impact on the progress of research in this area. Undoubtedly, the English-language publications had the greatest impact on the progress of research, although many researchers published their model proposals in their native languages. More important model combinations can be found in Harmon's (2009) publication, where he referred to fourteen articles presented in BPTrends.com during the period 2003-2009. The quoted articles refer to proposals from various environments: academia, industrial and industry centers, or consulting companies. Some publications are complete and provide the full set of information needed to implement the model in business practice, while other publications present the main framework of the model and the benefits of application. However, the full versions have been commercialized. The identification and comparison of the most recognizable models were also made by Rosemann and vom Brocke (2015), who presented nine models of process maturity that are the most important in the BPM trend. Another important analysis of business process maturity assessment models was made by Röglinger, Pöppelbuß, and Becker (2012), who identified further publications devoted to process maturity assessments, including: Willaert et 
al. (2007), McCormack (2007), Magdaleno et al. (2008), McCormack et al. (2009), Rohloff (2009). The study by Röglinger et al. (2012) is of particular value for researchers and practitioners, because the authors select the previously identified ten models due to their usefulness in managing business processes. At the same time, they analyze the spread of the models, indicate the lowest and highest level of process maturity, and provide a variety of information about the nature, purpose, adaptability and many other features of models, including sources of information about the models.

In view of the objectives of this study, the range of maturity of the processes included in individual models seems to be particularly important. The ongoing implementation of digital technologies supporting the implementation and management of business processes constitute the basis and the need to develop the concept of process maturity assessment. Of the ten models reported by Röglinger et al. (2012), only in two cases is the highest level of maturity associated with the use of integrated IT systems. This applies to the Business Process Maturity Model (BPMM) (Fisher, 2004), in which the lowest level of maturity is associated with a distributed and uncoordinated activity in the organization on process optimization, and the highest level means the creation of an intelligent operational network, thanks to which the efficiency of the entire chain is optimized and information flows freely, in realtime. The second model that directly relates to IT support is the Process and Enterprise Maturity Model (PEMM) (Hammer, 2007). The author of the model at the first indicated level of process maturity (P1) assumes that the process has not been designed as a comprehensive one, and that it is also supported by fragmented older IT systems. The highest level of maturity (P4) means that the process design matches the customer and supplier processes, and there is a modular IT architecture. Other models indicated in the study, such as BPM Maturity Model (BPMMM) (Rosemann \& Bruin, 2005); Process Performance Index (PPI) (Rummler \& Brache, 2012); BPR Maturity Model (BPRMM) (Maull et al., 2003); Process Management Maturity Assessment (PMMA) (Rohloff, 2009); BPO Maturity Model (BPOMM) (K. McCormack et al., 2009); Process Maturity Ladder (PML) (Harmon, 2019) and Business Process Maturity Model (BPMMOMG) (Weber et al., 2008), indicate maturity in a systemic perspective as the highest level of process maturity, but mainly in relation to process management systems and without indicating specific digital technologies that would be used in supporting implementation and process management.

The natural consequence is the continuation of research on the digital maturity of the organization. Various paths of digital maturity research have been outlined in the literature. So far, many research reports have been published presenting the current level of digital advancement of enterprises and forecasts for further development. 
For the analysis of changes in value chains, it is desirable to develop a method and methodologies for assessing the digital maturity of processes, so that it is possible to have a systemic view of the importance of digital technologies in achieving the business, social and environmental goals of various economic entities. The current proposals for a model approach to digital maturity, group the symptoms of digital maturation of enterprises in several areas, which gives the opportunity to develop them along with the development of digital technologies and progressing implementations. For example, the concept of Gill and Van Boskirk (2016) presented by Forrester includes four dimensions determining process maturity:

1) Culture - indicates the company's approach to digitally controlled innovation and the way in which it provides employees with access to digital technology.

2) Technology - defines the use and adoption of new technology by the company.

3) Organization - explains how the company adapted to support, manage and implement the digital strategy.

4) Insights - determines how well the company uses customer data and business data to measure success and create strategies.

In similar configurations, other models of digital maturity are presented, many of which can already be found, for example:

- Connected Enterprise Maturity Model (2016) developed at Rockwell Automation Inc. The maturity model includes a five-step approach to the implementation of Industry 4.0 (Assessment; Secure and upgraded network and controls; Defined and organized working data capital (WDC); Analytics; Collaboration). The assessment focused on the use of 4.0 technologies in the improvement of inventory management, delivery time, customer service, and efficiency;

- IMPULS - Industrie 4.0 Readiness (2015) developed in collaboration with VDMA, RWTH Aachen, and IW Consult. The model enables assessment in six dimensions including 18 items indicating readiness on five levels; defined barriers in moving to the next stage, as well as advice on how to overcome them;

- A maturity model for assessing Industry 4.0 readiness and maturity of manufacturing enterprises (Schumacher et al., 2016). The model is based on nine dimensions, to which 62 items have been assigned to assess the maturity of Industry 4.0. The test is based on a threestep procedure;

- Industry 4.0 maturity model - PwC (2016) covers four levels of digital enterprise maturity: 1. Digital Novice, 2. Horizontal (Internal 
Processes) Integrator, 3. Cooperating Vertically (with External Partners), 4. Digital Champion. Assessment of digital maturity is carried out according to seven groups of criteria:

- digital business model and customer access;

- digitization of the product portfolio;

- digitization, horizontal and vertical integration of the value chain;

- data and analysis as a key capability;

- agile IT structure;

- complaints handling, security, law and taxes;

- organization, employees, and digital culture.

The author of the article believes that the desirable direction would be to combine the assessment of process maturity and digital maturity for a better understanding of the changes taking place in the processes themselves and in their systemic approach in the value chain. An important question that should be asked is how to assess the digital maturity of a company, whether through technologies used in main production processes, where in the classic sense it is mainly focused on increasing efficiency, or in all processes, including supporting ones, which reflect the general level of digital competences of the enterprise, and therefore its development potential.

\section{Benchmarking research in the water sector}

Benchmarking initiatives are an important contribution to building knowledge in the water sector, especially on improving the performance of water utilities. Benchmarking research is, as a rule, relative. The obtained results refer to the real results regarding the quality of products and services and the efficiency of the activities of all enterprises, which was indicated by the researchers in the early periods of benchmarking, e.g. Partovi et al. (1994). Research on production capacity and costs is carried out in various scientific environments, both technical and economic disciplines. The application of the obtained research results, both in enterprises and by regulators, is unsatisfactory, especially in countries with middle and low incomes. Berg and Marques (2011), followed by Cetrulo et al. (2019), indicate examples of over two hundred quantitative studies, the importance of which for regulatory purposes turned out to be insignificant, for various reasons. They indicate a low level of trust in the conducted research, often also barriers on the side of technical competences, which are usually missing in the circles responsible for creating public policies. Berg's many years of research in collaboration with other researchers (Mugisha \& Berg, 2008; Berg, 2010; Berg \& Marques, 2011; Berg, 2013; Berg \& Phillips, 2017) and other researchers as Cabrera (2010) or Mugisha (2011) were devoted to the search for research methods 
that would increase the usefulness of the obtained research results, both for the main entities of the water sector, i.e. water companies, regulators and entities responsible for creating public policy in the industry.

By far, the most popular over the last two decades have been benchmarking studies based on key performance indicators (KPIs). Such examples are provided by the International Water Association (IWA) or The International Benchmarking Network for Water and Sanitation Utilities (IBNET) initiatives at the global level, the European Federation of National Association of Water Services (EurEau) at the European level, and various initiatives at the national or regional level, e.g. AQUABENCH, a special purpose company established by water companies from Germany, Austria and Switzerland, which started benchmarking in 1996. The impulse for such research was the remarkable development of the water supply industry in recent decades and undoubtedly the still strongly sustained pace of development. The observed increase in water production, distribution and wastewater treatment is due not only to the improvement of people's living standards in various regions, but also due to economic development in various sectors, where water is one of the most important resources. Water companies still face many challenges, the scale of which varies in different regions of the world, mainly due to the abundance and availability of water resources, or the level of advancement in environmental protection and, at the same time, protection of water resources. The challenges for the water sector highlighted in recent years, such as water quality and scarcity in many places around the world, aging infrastructure, stricter national and international regulatory requirements, climate change and pressure on environmental impact, bearing operating costs and capital investment, and changing demographics, are clearly reflected in research into the efficiency of water utilities. Examples include the US Environmental Protection Agency (EPA), which supports research in the development of water quality and safety legislation.

Comparative research conducted in the water sector, based primarily on performance indicators, is the result of changes in the understanding and research of business in connection with the dissemination of the concept of sustainable development based on multi-indicator analysis. In the scientific literature and business sources, many sets of indicators can be grouped and generalized. For example, KPI Institute (Minelli, 2021) conducted a secondary benchmarking study for the utilities sector, entitled Performance Benchmarking in the Water Utilities Sector. A total of 178 key performance indicators (KPIs) in five main areas are included in the report, of which the operational area is the best documented: 
1) Operation (68 KPIs, e.g. net energy consumption from water, tanks cleaned, restoration of unscheduled water supply within five hours, average time to restore sewers to service, etc.).

2) Customers ( $25 \mathrm{KPIs}$, e.g. water quality complaints per 100 customers, overall communication rate, billing accuracy, number of calls answered within 30 seconds, etc.).

3) Environment (22 KPIs, e.g. greenhouse gas emissions, \% waste going to landfill, \% solid waste recycled, paper consumption, total net $\mathrm{CO} 2$ emissions, etc.).

4) Human capital (61 KPIs, e.g. senior managers, share of women in senior management positions, rate of accidents related to lost time, male employees, \% of senior managers, etc.).

$5)$ Corporate governance (2 KPIs, number of meetings, number of employees entitled to participate in meetings).

Benchmarking studies evolve over time. According to Watson (1993a), the first benchmarking studies, which he classified as the first generation, had the most simplified form, related to product design (reverse benchmarking), comparing its most important features, functionality and possibilities in relation to other competing products. This type of comparative research dominated until the end of the 1980s. According to Watson, the second generation is competitive benchmarking, which dominated the next decade of the $1990 \mathrm{~s}$. This type of benchmarking was closely related to the development of various methods of strategic analysis of the environment. The third generation of comparative research development was dominated by process benchmarking, which developed on the basis of the popular Porter value chain model (Porter, 1980), initially based on basic functions and activities, later developed in relation to all processes carried out in enterprises. Hence, the next generation of research has been associated with the strategic importance of benchmarking in enterprises, relating to all its areas. Strategic benchmarking differs from the previous one in terms of greater scope and depth. This approach resulted in institutionalization of this activity in enterprises in the 90s. The next generation of comparative research was associated with the strong development of globalization and, at the same time, with easier access to information thanks to the global Internet network (Evans et al., 2012; Meybodi, 2015; Trento et al., 2016; Ebner et al., 2016; Ebner et al., 2019).

The Watson model has been the subject of many analyses and modifications, taking into account new trends in the economy. Many scholars have contributed to the development of knowledge on benchmarking, including Ahmed and Rafiq (1998), Kyrö (2003), Andad and Kodali (2008), Blancharrd et al. (2008), and Meybodi (2009). Recent research shows that new types of benchmarking are developing, e.g. intellectual capital benchmarking 
(Marti, 2000; Wudhikarn et al., 2020), competency benchmarking (Maciel \& Wallendorf, 2017; Castka \& Balzarova, 2018; Al Khamisi et al., 2019; Zhang, 2020; Brazinskas et al., 2021) or network benchmarking (De Toni \& Meneghetti, 2000; Walther \& Spengler, 2004; Zagkas \& Lyridis, 2011; Tsironis \& Matthopoulos, 2015). An essential contribution to the organization of knowledge on benchmarking was also made by Evans et al. (2012).

The newest, developing trend is Industry 4.0. Benchmarking is already used to make comparisons in the application of new digital technologies. You can already learn about this application of benchmarking from the article by Peruzzini et al. (2017), where they make comparisons in terms of communication and interaction of people and production systems in terms of work ergonomics. The impact of digital technologies on the organization studied using benchmarking has been presented in recent years by Lokuge et al. (2019), Gurbaxani and Dunkle (2019), Keller et al. (2019), and Härting et al.(2019).

Benchmarking studies also in water supply companies are carried out in all possible forms used so far. Undoubtedly, the most popular benchmarking projects, especially those with the greatest reach and scope, are based on the ratio analysis in terms of quality and efficiency obtained at the level of the entire enterprise. In line with the observation presented above, comparing indicators (KPIs) at the level of the entire enterprise gives a picture of possible achievements, perhaps facilitates the formulation of challenges, provides a vision for the development of the enterprise, and even business goals. However, it is of limited use in the operationalization of goals at the level of business processes.

\section{Value chain analysis}

The use of the value chain concept in the development of processes in the enterprise is now an indispensable starting point for understanding the role of the process approach in enterprise management. The value chain concept is now firmly established in business theory and practice. The value chain is a structure that allows one to organize various activities in organizations regardless of the sector of the economy or, in a narrower sense, an industry focused around a specific product or service. Therefore, the value chain has quickly become an attractive field of comparison for various economic actors. First of all, it allows you to get to know the structure of the activity, the connections of individual areas of the enterprise that occur in the processes, and the flows of resources and products taking place within them and between them, in order to ultimately deliver the expected value to customers. The deeper the analysis of the value chain is carried out, the more the field of observation for the various elements and their connections increases. 
Value chain analysis is used to achieve various corporate goals, not only business but also social and environmental. Interesting examples are provided by the studies of Villamayor-Tomas et al. (2015) on the use of value chain analysis to study the water-food-energy relationship, similarly to the studies by White et al. (2018). Other examples are also provided by research in the area of sustainable development (Ockwell et al., 2019), in which value chain analysis was used to develop payment methods (e.g., for water, energy) in line with the current real resource consumption. An important contribution to the development of this systems approach is the new research presented by Chofreh et al. (2019). They presented the benefits of mapping the water and wastewater value chain to contribute to sustainable development. The particular value of these studies is also expressed in their uniqueness because, from an academic perspective, there are few studies devoted to mapping the processes of the value chain of water and sewage systems. The research was carried out in a water company in Iran, and the results obtained by the researchers indicate the lack of integration of sustainable development in the water management system, which in turn leads to ineffectiveness. Experts' opinions in the presented studies indicate that mapping the value chain itself enables organizations to increase operational efficiency and eliminate waste by approx. 57\%. Other research examines the relationship between cost management tools and pricing policies to improve the price of potable water, which helps cover production costs on the one hand and rationalizes the consumption of the product on the other. This is done by utilizing the ActivityBased Costing (ABC) and Value Chain Analysis (VCA) to fix the cost and price of potable water (Al-Hashimi \& Jabbar, 2019). An equally interesting example of the use of value chain analysis is provided by the team of researchers, Choi et al. (2020). In their document, they presented the value chain and the stakeholder-oriented, product platform design process. Various options for the Water Treatment Products Platform were generated and assessed for their impact on the value chain, such as organizational structure, production line configuration, economic effect, and various stakeholders' preferences.

The starting point for carrying out a value chain analysis is to identify and organize the main and supporting business activities, i.e. value chain mapping (Vasanth Kumar et al., 2020). The constantly developing scope of activities undertaken in the enterprise, both basic and supportive, is most often the main reason for organizational and competence problems, and consequently for incurring larger, poorly controlled costs. Value chain mapping enables setting process boundaries and a precise definition of responsibilities, as well as process goals, necessary resources, and expected results. Mooney (2014), in his research, indicates the importance of subsequent stages of the value chain analysis for improving the quality and effectiveness of assessments of 
the obtained business results. When analyzing the usefulness of the value chain analysis for the needs of transforming business towards sustainable development, he pointed to several important benefits, e.g. the mapping process and further stages of the value chain analysis are also a platform for communication and discussion with stakeholders of water management.

The use of an appropriate methodology for mapping and analyzing the value chain requires an interdisciplinary perspective. The greatest experience in this area has been gathered by researchers of production processes, such as Haefner et al. (2014), who presented a value stream mapping method in order to design the required product quality in manufacturing companies. Tonelli et al. (2016) applied value mapping techniques to identify the value chain in manufacturing companies. Saguin (2018) used value chain mapping to identify access mechanisms in the value chain of urban aquaculture on a lake. This analysis was carried out to assess the social, economic and environmental relationships of urban aquaculture, reduce poverty and develop aquaculture strategies to promote sustainable development.

The latest trend of research using the concept of the value chain to conduct business activity is undoubtedly related to the possibilities provided by the latest digital technologies, which enable the collection of large amounts of data and the possibility of processing them and using them for business analytics. The current challenge is not how to get or produce data, but how to use it and turn it into something with a business character and value. Many researchers note the importance of understanding how companies apply the well-known Ackoff DIKW (Data, Information, Knowledge, and Wisdom) hierarchy in their value chains. This ability to turn data into wisdom in realtime mode puts pressure on companies to follow digital transformation (Welchman, 2015; Rothberg \& Erickson, 2017). Also, in the utilities sector, the way of thinking about using IT systems as a tool of strategic added value in decision-making is changing (Nagy et al., 2018; Schumacher et al., 2016; Liboni et al., 2018; Alcácer \& Cruz-Machado, 2019). This means that it is no longer a mere technological support activity as originally defined by Porter (1985) in his concept of the value chain. Currently, companies are already developing digital development strategies to better control and improve their value chains. 


\section{FRAMEWORK APPROACH TO BENCHMARKING THE DIGITIZATION OF PROCESSES IN VALUE CHAINS}

\section{Premises for benchmarking the digitization of processes}

Research to date shows that digitization makes value chains, both at the company level and globally, more efficient, flexible, and better customeroriented. The greatest potential of digital value chains to this prime is believed to be in Industry 4.0 and the fourth industrial revolution. It is assumed that ultimately, as digital technologies are implemented, virtually every area of business will be transformed through the vertical integration of R\&D, production, marketing and sales, and customer service along with all the supporting processes and activities. As a result, the economy is evolving towards an entire digital ecosystem based on technologies such as clouds (cloud), big data, the Internet of Things, 3D printing, augmented reality, and many others. The technologies themselves have already contributed to building new business partnerships and creating new digital business models. It is predicted that the next stage of economic development, possibly also revolutionary, may take place due to digital ecosystems in which already used and new technologies will be combined. This means even greater progress in making the value chain network more flexible and integrated, the possibility of virtualizing customer processes and interfaces, and tightening industry cooperation, which has already been articulated in research on the needs of various market entities (Transformation through innovation, ecosystems and sustained outcomes, PwC, May 28, 2021).

Low process competences are definitely one of the biggest implementation barriers. The use of a process approach in managing a water company, especially in smaller entities, is still at the implementation stage, and often pre-implementation. It is hard to disagree that the implementation of business process management is in itself a tedious and time-consuming process. Identifying the value chain, decomposing the chain within individual categories and groups of processes, and then mapping and measuring the processes requires a lot of work, developing appropriate process competences and implementing systems supporting process management, such as BPMS (Business Process Management System). Taking into account the different level of process maturity of water supply companies, different scenarios for making comparisons should be assumed. Process benchmarking conducted within the water supply industry, at the national or regional level, should undoubtedly take into account the level of process maturity of enterprises so that the knowledge provided by selected patterns (benchmarks) is useful and 
possible to be quickly used in enterprises using benchmarking. The presented concept of process benchmarking in the water supply industry serves primarily:

- quick recognition of digital technologies used in leading enterprises;

- obtaining information on the level of process and digital maturity of leading companies;

- assessment of the benefits obtained from the use of technologies (business, social and environmental);

- gaining knowledge about implementation processes and the necessary competences;

- assessment of the costs of purchasing and implementing new technologies.

Benchmarking the digitization of processes should primarily take into account:

- information on the processes (and their key elements) supported by digital technologies;

- information about the technologies used in the tested processes;

- information on the place of the analyzed processes in the structure of the value chain;

- information on the expected and obtained business, social and environmental benefits from the applied digital technologies;

- presentations of reference models of processes supported by digital technologies.

Even though process benchmarking is a valuable method used in the improvement of the organization, it has its limitations due to the timeconsuming nature and different standards of documenting processes. Therefore, there is a need to create benchmarking methodologies that will make it easier for enterprises to focus on those processes and technologies that release added value faster, understood both in a business, social and environmental sense.

\section{Scenarios for the use of the benchmarking methodology}

The presented approach to creating a benchmarking methodology for digitizing the value chain in water supply companies considers two alternative research scenarios. The first scenario (Figure 1) assumes using the current results obtained in benchmarking projects related to key performance indicators (KPIs). The previously identified indicators will make it possible to shorten the research process through a faster transition to the second stage 
of benchmark identification. It can be assumed that enterprises achieving more favorable performance indicators indicate a higher level of process and digital maturity. Thus, the probability of recruiting the most mature enterprises for research in the third stage increases. The assessment of process and digital maturity requires the use of maturity models adapted to the specifics of the entire industry, taking into account both legal regulations relating to the quality of supplied water and treated wastewater and environmental and social conditions. Determining the level of process and digital maturity of the analyzed processes is an important point of reference in designing measures for assessing the contribution of digital technologies in achieving company goals.

Benchmarking stages

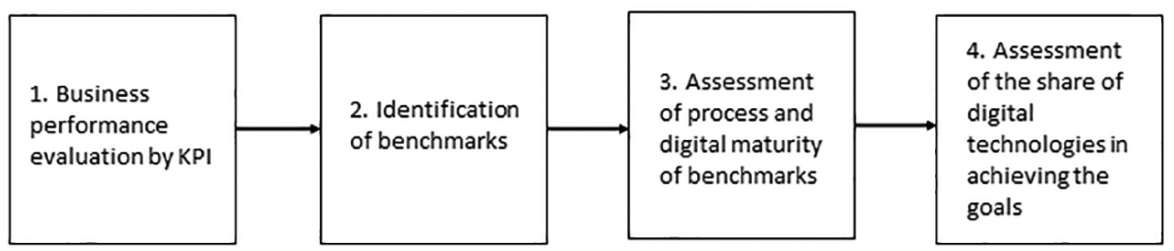

Figure 1. Stages of the research process - Scenario 1

The second scenario (Figure 2) is more demanding and increases the usefulness of the obtained research results for enterprises that would like to use this knowledge to develop their own business. The first stage of benchmarking research requires assessing the process and digital maturity of enterprises, taking into account both 3.0 and 4.0 technologies. For many companies, clients of benchmarking research, it is also important to refer not only to past technologies but also those that fit into the standards of water management. It is assumed that the above-average level of process and digital maturity should nominate companies to remain benchmarks. The process maturity scale should reach a range adequate to the target level of meeting stakeholders' expectations, the profitability of the conducted activity, and the acceptable environmental footprint.

The assessment of the digital advancement of enterprise processes in the third stage requires a multi-level creation of a matrix of processes in combination with digital technologies. The use of the enterprise value chain as a starting point for designing the levels of data refinement dictates decomposing the model. 
Benchmarking stages

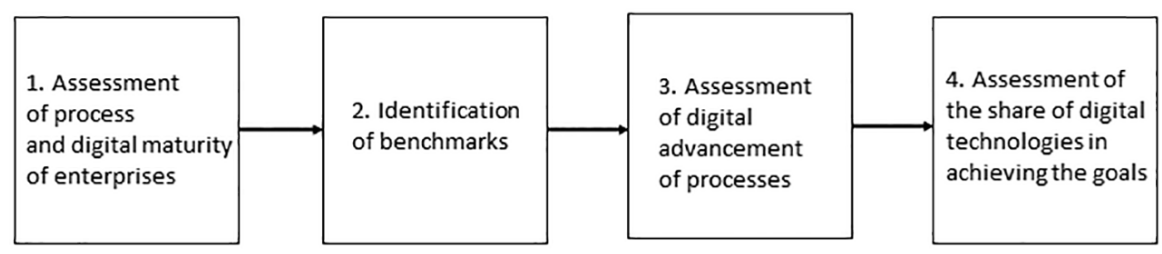

Figure 2. Stages of the research process - Scenario 2

The starting point for building a matrix is to establish the structure of the value chain and the set of digital technologies that will be the subject of the study. One of the most recognizable benchmarking models is the Process Classification Framework (PCF) model developed by the American Productivity \& Quality Center (APQC). The summary in Figure 3 relates to a PCF dedicated to Utilities. The PCF covers the decomposition of the value chain on five levels:

1) Process categories (14 categories).

2) Groups of processes within each category.

3) Processes within each group of processes.

4) Activities within each process.

5) Activities within the activity.

The use of an appropriate model of value chain decomposition should consider the specificity of enterprises within the industry under study.

Building a matrix for the purposes of benchmarking analysis results from the adopted structure of the value chain, and the analysis of the use of digital technologies can be performed at every level of the value chain, depending on the set research goals. Sample matrices are included in Figure 3. Each matrix in Figure 4 contains 14 process categories in the first column. This set, according to the PCF-Utilities/APQC model, starts with operational processes (1-6), and then supporting processes (7-14). The following columns contain: 1) First matrix: digital technologies selected for research; 2) Second matrix: functionalities of selected technologies; 3 ) Third matrix: the level of replacing human labor with machines; 4) Fourth matrix: the level of cost reduction by applying a given digital technology. 


\begin{tabular}{|c|c|c|c|c|c|}
\hline $\begin{array}{c}1.0 \text { Develop } \\
\text { Vision and } \\
\text { Strategy }\end{array}$ & $\begin{array}{l}2.0 \text { Develop and } \\
\text { Manage } \\
\text { Products and } \\
\text { Services }\end{array}$ & $\begin{array}{l}\text { 3.0 Market and } \\
\text { Sell Products } \\
\text { and Services }\end{array}$ & $\begin{array}{l}\text { 4.0 Deliver } \\
\text { Physical } \\
\text { Products }\end{array}$ & $\begin{array}{c}\text { 5.0 Deliver } \\
\text { Services }\end{array}$ & $\begin{array}{c}\text { 6.0 Manage } \\
\text { Customer } \\
\text { Service }\end{array}$ \\
\hline \multicolumn{6}{|c|}{ 7.0 Develop and Manage Human Capital } \\
\hline \multicolumn{6}{|c|}{ 8.0 Manage Information Technology (IT) } \\
\hline \multicolumn{6}{|c|}{ 9.0 Manage Financial Resources } \\
\hline \multicolumn{6}{|c|}{ 10. Acquire, Construct, and Manage Assets } \\
\hline \multicolumn{6}{|c|}{ 11. Manage Enterprise Risk, Compliance, Remediation, and Resiliency } \\
\hline \multicolumn{6}{|c|}{ 12. Manage External Relationships } \\
\hline \multicolumn{6}{|c|}{ 13. Develop and Manage Business Capabilities } \\
\hline \multicolumn{6}{|c|}{ 14. Operate Utility Assets } \\
\hline
\end{tabular}

Figure 3. Value chain of a water utility company

Source: Own study based on https://www.apqc.org/resource-library?f[0]=industry:2317

The number of matrices will depend on the scope of the research. Adding matrices is conceptual work. The number of matrices should depend on the research questions and, consequently, the structure of the research tools with which the data will be collected. The matrices presented in Figure 4 should answer the following questions: 1) What digital technologies are used in each process category?; 2) What functionalities of the selected technologies have been implemented?; 3) What is the level of replacing human work with digital technologies?; 4) What level of cost reduction in processes was achieved after the implementation of the selected technology?

Matrices used to assess the digitization of enterprise processes should include technologies already used in a given industry (in the case of water and sewage) or are likely to be implemented in the future. The sources used in the article indicate preliminary experiences and research and development works relating to many key technologies for Industry 4.0, e.g. mobile devices, loT platforms, location detection technology, advanced human-machine interfaces, authentication and fraud detection, intelligent sensors, Big analytics Data and advanced algorithms, multi-level interactions with customers and their profiling, augmented reality or cloud computing. 


\begin{tabular}{|c|c|c|c|c|c|c|c|c|c|c|c|c|c|c|c|c|c|c|c|c|}
\hline \multirow{2}{*}{$\begin{array}{l}\text { Process categories } \\
\text { in the value chain }\end{array}$} & \multicolumn{9}{|c|}{ Digital technologies } & \multirow{2}{*}{$\begin{array}{l}\text { Process categories } \\
\text { in the value chain }\end{array}$} & \multicolumn{10}{|c|}{$\begin{array}{c}\text { Functionalities of selected } \\
\text { technologies }\end{array}$} \\
\hline & 1 & 2 & 3 & 4 & 5 & 6 & 7 & 8 & \begin{tabular}{|l|l|}
9 & 10 \\
\end{tabular} & & 1 & 2 & 3 & 4 & 5 & 6 & 7 & 8 & 9 & 10 \\
\hline 1 & & & & & & & & & & 1 & & & & & & & & & & \\
\hline 2 & & & & & & & & & & 2 & & & & & & & & & & \\
\hline 3 & & & & & & & & & & 3 & & & & & & & & & & \\
\hline 4 & & & & & & & & & & 4 & & & & & & & & & & \\
\hline 5 & & & & & & & & & & 5 & & & & & & & & & & \\
\hline 6 & & & & & & & & & & 6 & & & & & & & & & & \\
\hline 7 & & & & & & & & & & 7 & & & & & & & & & & \\
\hline 8 & & & & & & & & & & 8 & & & & & & & & & & \\
\hline 9 & & & & & & & & & & 9 & & & & & & & & & & \\
\hline 10 & & & & & & & & & & 10 & & & & & & & & & & \\
\hline 11 & & & & & & & & & & 11 & & & & & & & & & & \\
\hline 12 & & & & & & & & & & 12 & & & & & & & & & & \\
\hline 13 & & & & & & & & & & 13 & & & & & & & & & & \\
\hline 14 & & & & & & & & & & 14 & & & & & & & & & & \\
\hline \multirow{2}{*}{$\begin{array}{l}\text { Process categories } \\
\text { in the value chain }\end{array}$} & \multicolumn{9}{|c|}{$\begin{array}{c}\text { The level of replacing human work by } \\
\text { technologies }\end{array}$} & \multirow{2}{*}{$\begin{array}{l}\text { Process categories } \\
\text { in the value chain }\end{array}$} & \multicolumn{10}{|c|}{$\begin{array}{c}\text { The level of reduction of process costs } \\
\text { through the use of technology }\end{array}$} \\
\hline & 1 & 2 & 3 & 4 & 5 & 6 & 7 & 8 & \begin{tabular}{|l|l|}
9 & 10 \\
\end{tabular} & & 1 & 2 & 3 & 4 & 5 & 6 & 7 & 8 & & 10 \\
\hline 1 & & & & & & & & & & 1 & & & & & & & & & & \\
\hline 2 & & & & & & & & & & 2 & & & & & & & & & & \\
\hline 3 & & & & & & & & & & 3 & & & & & & & & & & \\
\hline 4 & & & & & & & & & & 4 & & & & & & & & & & \\
\hline 5 & & & & & & & & & & 5 & & & & & & & & & & \\
\hline 6 & & & & & & & & & & 6 & & & & & & & & & & \\
\hline 7 & & & & & & & & & & 7 & & & & & & & & & & \\
\hline 8 & & & & & & & & & & 8 & & & & & & & & & & \\
\hline 9 & & & & & & & & & & 9 & & & & & & & & & & \\
\hline 10 & & & & & & & & & & 10 & & & & & & & & & & \\
\hline 11 & & & & & & & & & & 11 & & & & & & & & & & \\
\hline 12 & & & & & & & & & & 12 & & & & & & & & & & \\
\hline 13 & & & & & & & & & & 13 & & & & & & & & & & \\
\hline 14 & & & & & & & & & & 14 & & & & & & & & & & \\
\hline
\end{tabular}

Figure 4. Selected process digitization assessment matrices resulting from the decomposition of the value chain

The last stage of benchmarking research in the second scenario is assessing the share of digital technologies in achieving company goals (Figure 2). The knowledge obtained in process benchmarking is an opportunity to broaden the perspective of assessing business, social and environmental goals. Tracking changes in the structure of the value chain and in specific processes that occur thanks to digital technologies help develop knowledge about all elements of processes and their configuration. Each process is a specific system of goals, tasks, decisions, material and non-material resources, organizational roles, human and financial resources, quality and performance measures, risks and control activities, or flows and collaboration. The use of more and more advanced digital technologies leads to more and more significant changes in such systems. In line with the objectives of Business Process Improvement (BPI), benefits are obtained in the field of eliminating human and technical errors, reducing human activity in favor of intelligent machines, obtaining information about the course of processes in real-time, fast data processing, 
and decision making, e.g. thanks to the use of artificial intelligence, and above all, shortening the time of process implementation and reducing the consumption of resources, not only in production or operational processes but in all processes of the organization.

\section{Process benchmarking potential}

The essence of the benchmarking method relating to comparing oneself with more advanced or mature entities indicates unlimited possibilities for formulating goals, subject and subjective, spatial and temporal scopes, and research methodologies covering both the quantitative and qualitative approaches. Increasingly serious water management challenges arise before the management of any water company. Social expectations regarding unlimited access to high-quality water and sewerage services are at the same time related to the expectation of low prices for water and sewage services. Regulations concerning the shaping of tariffs are variable and do not always secure all water management stakeholders in the same way. Entities obliged to conduct collective water supply (e.g., local government units) and entities authorized to collect and treat water and collect and treat wastewater (plants, municipal companies) are obliged to conduct sustainable activities in the economic, social and environmental sense. Due to the level of technological advancement, legal obligations will become more and more detailed and demanding. An example of new research and regulatory perspectives is developing research into water and environmental footprint assessment. The ability to precisely measure the footprint of human activity and achieve better and better indicators should also be an important goal of benchmarking the digitization of business processes. Figure 5 shows the stages of benchmarking studies aimed at helping companies to identify the Environmental Footprint (similarly to Water Footprint) and to make efforts to improve their performance in this respect.

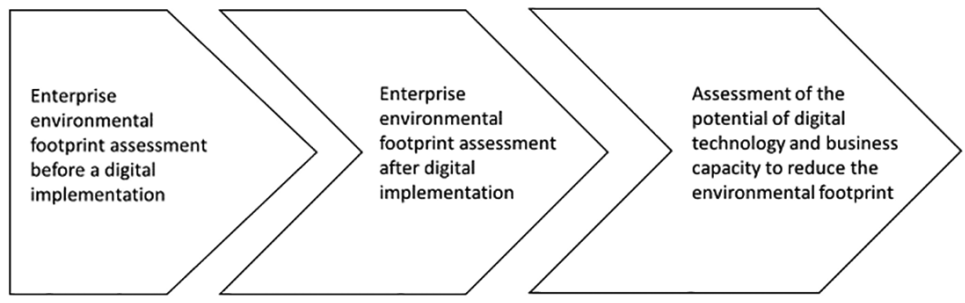

Figure 5. Assessment of the achievement of environmental goals in benchmarking 
Making an effort in enterprises to reduce the negative consequences of their activities requires rethinking their processes and taking actions towards their improvement or innovative reformulation. Therefore, it is necessary to develop the potential of benchmarking research, which, as a rule, should contribute to the diffusion of knowledge and improve the competencies of enterprises.

\section{CONCLUSIONS}

Digital technologies increasingly determine economic development, and therefore increasingly contribute to raising people's living standards and protecting the natural environment. Process benchmarking, as a method of improvement focused on building digital competences, is an important contribution to the digital development of enterprises. Observation and comparison of changes in processes under the influence of implemented digital technologies creates conditions for the interpretation of performance and quality indicators. From an enterprise business process-management perspective, it is easier to understand the impact of digital technologies because cost analysis is already at the process level rather than at the enterprise level. Assessment of the impact of digital technology on the increase in process efficiency allows for an evolutionary increase in digital maturity of processes. Observation of changes in enterprise value chains related to the digital technologies used should facilitate shortening the process of experimenting and learning on own implementation projects, and thus shortening implementation cycles and reducing the costs of implementing new technologies.

During the conducted literature studies and other sources of knowledge, mainly from business practice, which were presented in the article, the author tried to answer the research questions posed in the introduction. Research experiences in the field of digital maturity are steadily increasing. In response to the first question (RQ1) and after the analysis of Scopus and WoS database resources, it can be stated that starting from 2006, individual studies on the digital maturity of various entities were published. In both cases, 2018 saw a two-fold increase in Scopus and a three-fold increase in the number of publications in WoS devoted to digital maturity. One can also notice an increasing dynamics of interest in research issues. Research is carried out in many sectors, but there are still no examples relating to water utilities. The combination of digital process maturity methodology and value chain analysis was also not identified. The author initiated the concept of researching the digital maturity of the processes forming the value chain, 
filling the research gap in the benchmarking methodology in the water sector. The research concept can also inspire similar research in other sectors.

In the next stage of the literature review, the author looked for an answer to the question (RQ2): what research approaches are used in benchmarking water supply companies? The identification and analysis of scientific sources as well as the review of websites and internet platforms allows us to conclude that benchmarking of water companies based on KPIs definitely dominates in both the scientific and business environments. Work on defining indicators related to digital technologies is progressing, but they are not popular in the water sector. In summing up the analysis relating to the next question (RQ3), it should be noted that there is also little interest in the analysis of the value chain in the water supply industry. There are individual articles indexed in Scopus and WoS that demonstrate the application of the value chain to comparative research in the water sector. However, compared to other sectors, the popularity of the issue is low. Therefore, it can be concluded that this is further evidence of a research gap.

The fourth research question (RQ4) concerned the concept of benchmarking methodology. After analyzing the applied benchmarking research and examining the popularity of process benchmarking, two possible research scenarios were proposed. The first scenario takes into account the achievements so far in the benchmarking respondents based on KPIs. Knowledge of the obtained performance indicators allows you to shorten the time of benchmark identification and focus on selected, key processes for water supply companies. The second scenario of benchmarking research assumes a systemic approach to research, which uses the structure of the value chain and the already popularized methodologies for assessing process maturity. Such research allows for a complete picture of the involvement of digital technologies in enterprise value chains. The author tried to emphasize the same role of digitization of operational and supporting processes and their impact on the achievement of economic, social and environmental goals of enterprises. In the analysis of the environment of a modern water company and its value chain, the issue of sustainable development cannot be ignored, which she also tried to highlight.

Process benchmarking is valuable not only for technologically less developed companies but also for technology leaders in the industry. Comparing yourself with other leading entities serves to look for inspiration to create innovative solutions, as well as build business and public-business partnerships in order to increase economic, social and environmental value. Benchmarking studies are conducted by individual enterprises, but the most popular, both in the scientific and business environment, are studies conducted on a wider scale (regional, national or international). Hence, the 
initiated concept of benchmarking the digitization of the value chain can also be developed on a larger scale, for example by industry organizations, in public initiatives, and in public-private partnership.

Further directions of research on the benchmarking methodology for digitizing the value chain should be aimed at establishing a set of indicators and levels of digital maturity for current and future digital technologies in the water sector. The next stage in developing the proposed benchmarking methodology requires empirical identification of indicators and testing of scales to determine the levels of digital maturity of processes.

\section{Acknowledgment}

The work was carried out as part of statutory research. Title of the research task: Identifying changes in the value chains in process terms

\section{Reference}

Ahmed, P., \& Rafiq, M. (1998). Integrated benchmarking: A holistic examination of select techniques for benchmarking analysis. Benchmarking for Quality Management \& Technology, 5(3), 225-242. https://doi. org/10.1108/14635779810234802

Ahmed, T., Fung, A. S., \& Kumar, R. (2020). Energy benchmarking and ventilation related energy saving potentials for SMEs in Greater Toronto Area. Journal of Cleaner Production, 246. https://doi.org/10.1016/j. jclepro.2019.118961

Al Khamisi, Y. N., Khan, M. K., \& Munive-Hernandez, J. E. (2019). Knowledgebased lean six sigma system for enhancing quality management performance in healthcare environment. International Journal of Lean Six Sigma, 10(1), 211-233. https://doi.org/10.1108/IJLSS-06-2017-0066

Al Nuseirat, A. A., El Kahlout, Z. M., Abbas, A., Adebanjo, D., Punnakitikashem, P., \& Mann, R. (2019). An analysis of a structured benchmarking project: The case of Dubai Electricity and Water Authority's benchmarking project. Benchmarking, 26(5), 1431-1450. https://doi.org/10.1108/BIJ02-2018-0032

Alcácer, V., \& Cruz-Machado, V. (2019). Scanning the Industry 4.0: A literature review on technologies for manufacturing systems. Engineering Science and Technology, an International Journal, 22(3), 899-919. https://doi. org/10.1016/j.jestch.2019.01.006

Aldrich, H. E. (1999). Organizations Evolving. London, Thousand Oaks, New Delhi: Sage Publications.

Al-Hashimi, A. M., \& Jabbar, A. A.-H. (2019). Role of integrating ABC and VCA through the use of supply chain management in improving potable water tariff in Iraq. International Journal of Supply Chain Management, 8(1), 546-561. 
Allan, F. (1993). Benchmarking-Practical aspects for information professionals. Special Libraries, 84(3), 123-130.

Allard, A. (1967). Evolution and Human Behavior. New York: Natural History Press. Anand, G., \& Kodali, R. (2008). Benchmarking the benchmarking models. Benchmarking-an International Journal, 15(3), 257-291. https://doi. org/10.1108/14635770810876593

Baldwin, R., \& Venables, A. J. (2015). Trade policy and industrialization when backward and forward linkages matter. Research in Economics, 69(2), 123-131. https://doi.org/10.1016/j.rie.2015.02.008

Beath, A., \& Flynn, C. (2020). Benchmarking the performance of private equity portfolios of the World's largest institutional investors: A view from CEM benchmarking. Journal of Index Investing, 30(1), 67-87. https://doi. org/10.3905/joi.2020.1.155

Berg, S. (2010). Water Utility Benchmarking: Measurement, Methodologies and Performance Incentives. London: IWA Publishing. Retrieved from https://www.iwapublishing.com/ books/9781843392729/water-utilitybenchmarking

Berg, S. (2013). Advances in benchmarking to improve water utility operations: A review of six IWA books. Water Policy, 15(2), 325-333. https://doi. org/10.2166/wp.2012.089

Berg, S., \& Marques, R. (2011). Quantitative studies of water and sanitation utilities: A benchmarking literature survey. Water Policy, 13(5), 591-606. https://doi.org/10.2166/wp.2011.041

Berg, S. V., \& Phillips, M. A. (2017). Data availability as a key tool for regulating government-owned water utilities. Utilities Policy, 49, 30-37. https:// doi.org/10.1016/j.jup.2017.06.012

Bickauske, D., Simanaviciene, Z., Jakubavicius, A., Vilys, M., \& Mykhalchyshyna, L. (2020). Analysis and perspectives of the level of enterprises digitalization (Lithuanian manufacturing sector case). Independent Journal of Management \& Production, 11(9), 2291-2307. https://doi. org/10.14807/ijmp.v11i9.1404

Blanchard, C., Comm, C. L., \& Mathaisel, D. F. X. (2008). Adding value to service providers: Benchmarking Wal-Mart. Benchmarking-an International Journal, 15(2), 166-177. https://doi.org/10.1108/14635770810864875

Brazinskas, S., Pipiriene, V., \& Khayrzoda, S. (2021). Digital platforms: Drivers for competence and competitiveness growth. International Journal of Learning and Change, 13(4-5), 490-509. https://doi.org/10.1504/ IJLC.2021.116695

Broberg, P., Umans, T., Skog, P., \& Theodorsson, E. (2018). Auditors' professional and organizational identities and commercialization in audit firms. Accounting, Auditing and Accountability Journal, 31(2), 374-399. https://doi.org/10.1108/AAAJ-02-2014-1607

Bustinza, O. F., Bigdeli, A. Z., Baines, T., \& Elliot, C. (2015). Servitization and competitive advantage: The importance of organizational structure and 
value chain position. Research-Technology Management, 58(5), 53-60. https://doi.org/10.5437/08956308X5805354

Cabrera, E. Jr., Dane, P., Haskins, S., \& Theuretzbacher-Fritz, H. (2010). Benchmarking Water Services: Guiding Water Utilities to Excellence. London: IWA Publishing. Retrieved from https://www.iwapublishing. com/books/9781843391982/benchmarking -water-services

Camp, R. C. (1989). Benchmarking: The search for industry best practices that lead to superior performance. Quality Progress, 22(4), 62-69.

Campbell, D. (1969). Variation and selective retention in socio-cultural evolution. General Systems, 14, 69-85.

Castka, P., \& Balzarova, M. A. (2018). An exploration of interventions in ISO 9001 and ISO 14001 certification context - A multiple case study approach. Journal of Cleaner Production, 174, 1642-1652. https://doi. org/10.1016/j.jclepro.2017.11.096

Cetrulo, T. B., Marques, R. C., \& Malheiros, T. F. (2019). An analytical review of the efficiency of water and sanitation utilities in developing countries. Water Research, 161, 372-380. https://doi.org/10.1016/j. watres.2019.05.044

Chofreh, A. G., Goni, F. A., Zeinalnezhad, M., Navidar, S., Shayestehzadeh, H., \& Klemes, J. J. (2019). Value chain mapping of the water and sewage treatment to contribute to sustainability. Journal of Environmental Management, 239, 38-47. https://doi.org/10.1016/j. jenvman.2019.03.023

Choi, S. C., Suh, E. S., \& Park, C. J. (2020). Value chain and stakeholder-driven product platform design. Systems Engineering, 23(3), 312-326. https:// doi.org/10.1002/sys.21527

Christiansson, M.-T., \& Rentzhog, O. (2020). Lessons from the "BPO journey" in a public housing company: Toward a strategy for BPO. Business Process Management Journal, 26(2), 373-404. https://doi.org/10.1108/BPMJ04-2017-0091

Daniels, S. (1996). Benchmarking. Work Study, 45(3), 18-20.

Daraio, C., Kerstens, K., Nepomuceno, T., \& Sickles, R. C. (2020). Empirical surveys of frontier applications: A meta-review. International Transactions in Operational Research, 27(2), 709-738. https://doi.org/10.1111/itor.12649

De Toni, A., \& Meneghetti, A. (2000). Production planning process for a network of firms in the textile-apparel industry. International Journal of Production Economics, 65(1), 17-32. https://doi.org/10.1016/S09255273(99)00087-0

Delpachitra, S., \& Beal, D. (2002). Process benchmarking: An application to lending products. Benchmarking, 9(4), 409-420. https://doi. org/10.1108/14635770210442725

Ebner, K., Mueller, B., \& Ahlemann, F. (2019). Understanding the success of strategic IT benchmarking-Exploring the role of the individual level. Information and Management, 56(5), 640-656. https://doi. org/10.1016/j.im.2018.10.005 
Ebner, K., Urbach, N., \& Mueller, B. (2016). Exploring the path to success: A review of the strategic IT benchmarking literature. Information and Management, 53(4), 447-466. https://doi.org/10.1016/j.im.2015.11.001 Evans, M. T. P., Tisak, D. J., \& Williamson, D. F. (2012). Twentyfirst century benchmarking: Searching for the next generation. Benchmarking-an International Journal, 19(6), 760-780. https://doi. org/10.1108/14635771211284314

Fernandez, P., Mccarthy, I. P., \& Rakotobe-Joel, T. (2001). An evolutionary approach to benchmarking. Benchmarking: An International Journal, 8(4), 281-305. https://doi.org/10.1108/14635770110403783

Ferreira, D. C., \& Marques, R. C. (2021). Public-private partnerships in health care services: Do they outperform public hospitals regarding quality and access? Evidence from Portugal. Socio-Economic Planning Sciences, 73. https://doi.org/10.1016/j.seps.2020.100798

Fisher, D. M. (2004). The business process maturity model. A practical approach for identifying opportunities for optimization. BPTrend. Retrieved 2 May, 2021, from https://www.bptrends.com/bpt/wpcontent/publicationfiles/10-04\%20ART\%20B P\%20Maturity\%20 Model\%20-\%20Fisher.pdf

Fonseca, L. M. (2018). Industry 4.0 and the digital society: Concepts, dimensions and envisioned benefits. Proceedings of the International Conference on Business Excellence, 12(1), 386-397. https://doi. org/10.2478/picbe-2018-0034

Francisco, A., Mohammadi, N., \& Taylor, J. E. (2020). Smart city digital twinenabled energy management: Toward real-time urban building energy benchmarking. Journal of Management in Engineering, 36(2). https:// doi.org/10.1061/(ASCE)ME.1943-5479.0000741

Garzoni, A., De Turi, I., Secundo, G., \& Del Vecchio, P. (2020). Fostering digital transformation of SMEs: A four levels approach. Management Decision, 58(8), 1543-1562. https://doi.org/10.1108/MD-07-2019-0939

Gill, M., \& Van Boskirk, S. (2016). The Digital Maturity Model 4.0. Benchmarks: Digital Business Transformation Playbook. Forrester Research, Inc. Retrieved 5 May, 2021, from https://forrester.nitro-digital.com/pdf/ Forrester-s\%20Digital\%20Maturity\%20Model\%204.0.pdf

Glavan, L. M. (2020). An investigation of business process maturity: Report on Croatian companies. Business Systems Research, 11(2), 159-165. https://doi.org/10.2478/bsrj-2020-0022

Gleeson, T., Wada, Y., Bierkens, M. F. P., \& Van Beek, L. P. H. (2012). Water balance of global aquifers revealed by groundwater footprint. Nature, 488(7410), 197-200. https://doi.org/10.1038/nature11295

Goni, F. A., Gholamzadeh Chofreh, A., Estaki Orakani, Z., Klemes, J. J., Davoudi, M., \& Mardani, A. (2021). Sustainable business model: A review and framework development. Clean Technologies and Environmental Policy, 23(3), 889-897. https://doi.org/10.1007/s10098-020-01886-z 
Graetz, G., \& Michaels, G. (2018). Robots at work. Review of Economics and Statistics, 100(5), 753-768. https://doi.org/10.1162/rest_a_00754

Gurbaxani, V., \& Dunkle, D. (2019). Gearing up for successful digital transformation. MIS Quarterly Executive, 18(3), 209-220. https://doi. org/10.17705/2msqe.00017

Haefner, B., Kraemer, A., Stauss, T., \& Lanza, G. (2014). Quality value stream mapping. Procedia CIRP, 17, 254-259. https://doi.org/10.1016/j. procir.2014.01.093

Hammer, M. (2007). The process audit. Harvard Business Review. April, 111123. Retrieved 15 November, 2020, from https://hbr.org/2007/04/theprocess-audit

Harmon, P. (2009). Process maturity models. BPTrends, 2(5). Retrieved 5 May, 2021 from https://www.bptrends.com/bpt/wp-content/publicationfiles/ spotlight_051909.pdf

Harmon, P. (2019). Business process change: A business process management guide for managers and process professionals. Burlington: Morgan Kaufmann. https://doi.org/10.1016/C2017-0-02868-9

Härting, R.-C., Reichstein, C., \& Sochacki, R. (2019). Potential benefits of digital business models and its processes in the financial and insurance industry. Smart Innovation, Systems and Technologies, 143, 205-216. https://doi.org/10.1007/978-981-13-8303-8_18

Hoekstra, A. Y., Chapagain, A. K., \& van Oel, P. R. (2019). Progress in water footprint assessment: Towards collective action in water governance. Water (Switzerland), 11(5). https://doi.org/10.3390/w11051070

Hurmelinna, P., Peltola, S., Tuimala, J., \& Virolainen, V.-M. (2002). Attaining world-class R\&D by benchmarking buyer-supplier relationships. International Journal of Production Economics, 80(1), 39-47. Scopus. https://doi.org/10.1016/S0925-5273(02)00241-4

Keller, T., Bayer, C., Bausch, P., \& Metternich, J. (2019). Benefit evaluation of digital assistance systems for assembly workstations. Procedia CIRP 81, 441-446. https://doi.org/10.1016/j.procir.2019.03.076

Khosravi, A. (2016). Business process rearrangement and renaming: A new approach to process orientation and improvement. Business Process Management Journal, 22(1), 116-139. https://doi.org/10.1108/BPMJ02-2015-0012

Kulikowski, K. (2021). Cognitive biases policy (CBP) in performance improvements - the example of benchmarking. International Journal of Productivity and Performance Management. https://doi.org/10.1108/ IJPPM-02-2020-0060

Kyrö,P.(2003). Revising the conceptand forms of benchmarking. Benchmarking, 10(3), 210-225. https://doi.org/10.1108/14635770310477753

Liboni, L. B., Liboni, L. H. B., \& Cezarino, L. O. (2018). Electric utility 4.0: Trends and challenges towards process safety and environmental protection. Process Safety and Environmental Protection, 117, 593-605. https://doi. org/10.1016/j.psep.2018.05.027 
Lichtblau, K., Stich, V., Bertenrath, R., Blum, M., Bleider, M., Millack, A., Schmitt, K., Schmitz, E., \& Schröter, M. (2015). Industry 4.0 Readiness. The IMPULS Foundation of the German Engineering Federation (VDMA). Retrieved 25 February, 2021, from http://industrie40.vdma. org/documents/4214230/5356229/Industrie\%204.0\%20Readiness\%20 Study\%20English.pdf/f6de92c1-74ed-4790-b6a4-74b30b1e83fo

Lokuge, S., Sedera, D., Grover, V., \& Dongming, X. (2019). Organizational readiness for digital innovation: Development and empirical calibration of a construct. Information and Management, 56(3), 445-461. https:// doi.org/10.1016/j.im.2018.09.001

Looy, A. V. (2020). Capabilities for managing business processes: A measurement instrument. Business Process Management Journal, 26(1), 287-311. https://doi.org/10.1108/BPMJ-06-2018-0157

Lopes, A. L. M., De Barros Mesquita, R., Lambertucci, M., \& Lara, J. E. (2020). The evolution of the benchmarking methodology data envelopment analysis-DEA in the cost regulation of the Brazilian electric power transmission sector: A critical look at the renewal of concessions. Gestao e Producao, 27(1). https://doi.org/10.1590/0104-530X3940-20

Luo, M., Fan, H. Q., \& Liu, G. (2020). Measuring regional differences of construction productive efficiency in China: A distance friction minimization approach. Engineering, Construction and Architectural Management, 27(4), 952-974. https://doi.org/10.1108/ECAM-04-2019-0195

Maciel, A. F., \& Wallendorf, M. (2017). Taste engineering: An extended consumer model of cultural competence constitution. Journal of Consumer Research, 43(5), 726-746. https://doi.org/10.1093/jcr/ucw054

Magdaleno, A. M., Cappelli, C., Baião, F. A., Santoro, F. M., \& Araujo, R. (2008). Towards collaboration maturity in business processes: An exploratory study in oil production processes. Information Systems Management, 25(4), 302-318. https://doi.org/10.1080/10580530802384159

Malik, R., Mann, R., \& Knapman, R. (2021). Rapid benchmarking: The case of a multinational dairy company. Benchmarking-an International Journal, 28(3), 1031-1058. https://doi.org/10.1108/BIJ-03-2020-0099

Marti, J. M. V. (2000). ICBS Intellectual Capital Benchmarking Systems. International Journal of Technology Management, 20(5-8), 799-818. https://doi.org/10.1504/IJTM.2000.002890

Maull, R. S., Tranfield, D. R., \& Maull, W. (2003). Factors characterizing the maturity of BPR programmes. International Journal of Operations and Production Management, 23(5-6), 596-624. https://doi. org/10.1108/01443570310476645

McCormack, D. K. (2007). Business Process Maturity: Theory and Application. Charleston: BookSurge.

McCormack, K., Willems, J., van den Bergh, J., Deschoolmeester, D., Willaert, P., Štemberger, M. I., Škrinjar, R., Trkman, P., Ladeira, M. B., de Oliveira, M. P. V., Vuksic, V. B., \& Vlahovic, N. (2009). A global investigation of key turning 
points in business process maturity. Business Process Management Journal, 15(5), 792-815. https://doi.org/10.1108/14637150910987946

Meybodi, M. Z. (2009). Benchmarking performance measures in traditional and just-in-time companies. Benchmarking-an International Journal, 16(1), 88-102. https://doi.org/10.1108/14635770910936531

Meybodi, M. Z. (2015). Consistency of strategic and tactical benchmarking performance measures: A perspective on managerial positions and organizational size. Benchmarking, 22(6), 1019-1032. https://doi. org/10.1108/BIJ-07-2013-0074

Minelli, A. (2021). Performance Benchmarking in the Water Utilities Sector. Melbourne: KPI Institute. Retrieved 2 February, 2021, from https://www. performancemagazine.org/benchmarking-water-utilities-sector/

Miri-Lavassani, K., \& Movahedi, B. (2018). Achieving higher supply chain performance via business process orientation. Business Process Management Journal, 24(3), 671-694. https://doi.org/10.1108/BPMJ07-2016-0140

Mooney, C. L. (2014). Five reasons corporate responsibility professionals need a value chain map. GreenBiz. Retrieved 5 February, 2021, from https:// greenbiz.com/blog/2014/01/09/5-reasons-cr-professionals -needvaluechain-map

Morse, L., Trompet, M., Barron, A., Anderson, R., \& Graham, D. J. (2020). A benchmarking framework for understanding bus performance in the US. Benchmarking, 27(4), 1533-1550. https://doi.org/10.1108/BIJ-082019-0367

Movahedi, B., Miri-Lavassani, K., \& Kumar, U. (2016). Operational excellence through business process orientation: An intra- and inter-organizational analysis. TQM Journal, 28(3), 467-495. https://doi.org/10.1108/TQM12-2013-0147

Mugisha, S. (2011). Utility benchmarking and regulation in developing countries: Practical application of performance monitoring and incentives. London: IWA Publishing.

Mugisha, S., \& Berg, S. V. (2008). State-owned enterprises: NWSC's turnaround in Uganda. African Development Review, 20(2), 305-334. https://doi. org/10.1111/j.1467-8268.2008.00188.x

Muntean, M. (2018). Business intelligence issues for sustainability projects. Sustainability, 10(2), 335. https://doi.org/10.3390/su10020335

Nagy, J., Oláh, J., Erdei, E., Máté, D., \& Popp, J. (2018). The role and impact of industry 4.0 and the internet of things on the business strategy of the value chain-the case of hungary. Sustainability (Switzerland), 10(10). https://doi.org/10.3390/su10103491

Novak, R., \& Janeš, A. (2019). Business process orientation in the Slovenian power supply. Business Process Management Journal, 25(4), 780-798. https://doi.org/10.1108/BPMJ-05-2017-0130

Ockwell, D., Atela, J., Mbeva, K., Chengo, V., Byrne, R., Durrant, R., Kasprowicz, V., \& Ely, A. (2019). Can pay-as-you-go, digitally enabled business 
models support sustainability transformations in developing countries? Outstanding questions and a theoretical basis for future research. Sustainability (Switzerland), 11(7). https://doi.org/10.3390/su10022105 Pace, L. A., \& Kelly, E. P. (1998). TQM at Xerox: Lessons worth duplicating. International Journal of Technology Management, 16(4-6), 326-335. https://doi.org/10.1504/ijtm.1998.002678

Pagani, M., \& Pardo, C. (2017). The impact of digital technology on relationships in a business network. Industrial Marketing Management, 67, 185-192. https://doi.org/10.1016/j.indmarman.2017.08.009

Partovi, F. Y., \& Hopton, W. E. (1994). Analytic hierarchy process as applied to two types of inventory problems. Production and Inventory Management Journal, 35(1), 13-19.

Peruzzini, M., Grandi, F., \& Pellicciari, M. (2017). Benchmarking of tools for User eXperience analysis in Industry 4.0. Procedia Manufacturing, 27th International Conference on Flexible Automation and Intelligent Manufacturing, Faim2017, 11, pp. 806-813. https://doi.org/10.1016/j. promfg.2017.07.182

Ponomarenko, V. (2019). The applicability of process-orientation to software development projects: The applicability of process-orientation to software development projects. International Journal of Information Technology Project Management, 10(2), 1-7. https://doi.org/10.4018/ IJITPM.2019040101

Porter, M. E. (1985). Competitive advantage: Creating and sustaining superior performance. London: Collier Macmillan.

Porter, M. E. (1980). Competitive strategy: Techniques for analyzing industries and competitors. New York: Free Press.

Potoczek, N. (2017). The role of human resource management in achieving process maturity by organizations. In Z. Ndaba \& T. Mokoteli (Eds.), Proceedings of the 5th International Conference on Management, Leadership and Governance (pp. 371-379). Johannesburg, South Africa: University of Witwatersrand, Wits Business School. Retrieved from https://www.webofscience.com/wos/woscc/summary/f4fd8e94-8c504178-b53a-557eb1014f4f-06c58406/relevance/1

Röglinger, M., Pöppelbuß, J., \& Becker, J. (2012). Maturity models in business process management. Business Process Management Journal, 18(2), 328-346. https://doi.org/10.1108/14637151211225225

Rohloff, M. (2009). Case study and maturity model for business process management implementation. Lecture Notes in Computer Science (Including Subseries Lecture Notes in Artificial Intelligence and Lecture Notes in Bioinformatics), 5701 LNCS, 128-142. https://doi. org/10.1007/978-3-642-03848-8_10

Rosemann, M., \& Bruin, T. (2005). Towards a Business Process Management Maturity Model. ECIS 2005 Proceedings. Retrieved from https://aisel. aisnet.org/ecis2005/37 
Rosemann, M., \& vom Brocke, J. (2015). The six core elements of business process management. In Handbook on Business Process Management 1 (pp. 105-122). Berlin Heidelberg: Springer-Verlag. https://doi. org/10.1007/978-3-642-45100-3

Rothberg, H. N., \& Erickson, G. S. (2017). Big data systems: Knowledge transfer or intelligence insights? Journal of Knowledge Management, 21(1), 92112. https://doi.org/10.1108/JKM-07-2015-0300

Rummler, G. A., \& Brache, A. P. (2012). Improving Performance: How to Manage the White Space on the Organization Chart. New York: John Wiley \& Sons.

Saguin, K. (2018). Mapping access to urban value chains of aquaculture in Laguna Lake, Philippines. Aquaculture, 493, 424-435. https://doi. org/10.1016/j.aquaculture.2017.01.030

Salim, Z., Pranata, N., \& Sabilla, K. (2020). Benchmarking Singapore and Hong Kong to develop Indonesia's trade facilitation. International Journal of Business and Globalisation, 26(1-2), 119-147. https://doi.org/10.1504/ IJBG.2020.109829

Schumacher, A., Erol, S., \& Sihn, W. (2016). A maturity model for assessing Industry 4.0 readiness and maturity of manufacturing enterprises. In A. Nassehi \& S. Newman (Eds.), Sixth International Conference on Changeable, Agile, Reconfigurable and Virtual Production (Vol. 52, pp. 161-166). Amsterdam: Elsevier Science Bv. https://doi.org/10.1016/j. procir.2016.07.040

Shafagatova, A., \& Van Looy, A. (2021). A conceptual framework for processoriented employee appraisals and rewards. Knowledge and Process Management, 28(1), 90-104. https://doi.org/10.1002/kpm.1644

Shetty, Y. (1993). Aiming high-Competitive benchmarking for superior performance. Long Range Planning, 26(1), 39-44. https://doi. org/10.1016/0024-6301(93)90231-4

Sommarberg, M., \& Makinen, S. J. (2019). A method for anticipating the disruptive nature of digitalization in the machine-building industry. Technological Forecasting and Social Change, 146, 808-819. https://doi. org/10.1016/j.techfore.2018.07.044

Telnov, Y. F., Kazakov, V. A., \& Trembach, V. M. (2020). Developing a knowledgebased system for the design of innovative product creation processes for network enterprises. Biznes Informatika-Business Informatics, 14(3), 35-53. https://doi.org/10.17323/2587-814X.2020.3.35.53

Tonelli, F., Demartini, M., Loleo, A., \& Testa, C. (2016). A novel methodology for manufacturing firms value modeling and mapping to improve operational performance in the Industry 4.0 Era. Procedia CIRP, 57, 122127. https://doi.org/10.1016/j.procir.2016.11.022

Trabucchi, D., Buganza, T., Dell'Era, C., \& Pellizzoni, E. (2018). Exploring the inbound and outbound strategies enabled by user generated big data: Evidence from leading smartphone applications. Creativity and Innovation Management, 27(1), 42-55. https://doi.org/10.1111/caim.12241 
Trento, C. R., Stüker, T., Pereira, G. M., Borchardt, M., \& Viegas, C. V. (2016). Strategic benchmarking of service pricing based on the value added. Benchmarking, 23(4), 754-767. https://doi.org/10.1108/BIJ-07-2013-0073

Tsironis, L. K., \& Matthopoulos, P. P. (2015). Towards the identification of important strategic priorities of the supply chain network: An empirical investigation. Business Process Management Journal, 21(6), 1279-1298. https://doi.org/10.1108/BPMJ-12-2014-0120

Valdez-De-Leon, O. (2019). How to develop a digital ecosystem: A practical framework. Technology Innovation Management Review, 9(8), 43-54. https://doi.org/10.22215/timreview/1260

van Assen, M. (2018). Process orientation and the impact on operational performance and customer-focused performance. Business Process Management Journal, 24(2), 446-458. https://doi.org/10.1108/BPMJ10-2016-0217

Vasanth Kumar, D., Madhan Mohan, G., \& Mohanasundaram, K. M. (2020). Lean supply chain management in garment industry using value stream mapping. International Journal of Services and Operations Management, 37(1), 133-143. https://doi.org/10.1504/IJSOM.2020.109440

Villamayor-Tomas, S., Grundmann, P., Epstein, G., Evans, T., \& Kimmich, C. (2015). The water-energy-food security nexus through the lenses of the value chain and the institutional analysis and development frameworks. Water Alternatives, 8(1), 735-755.

Walker, R. (1992). Rank Xerox-Management revolution. Long Range Planning, 25(1), 9-21. https://doi.org/10.1016/0024-6301(92)90305-I

Walther, G., \& Spengler, T. (2004). Empirical analysis of collaboration potential of SMEs in product recovery networks in Germany. Progress in Industrial Ecology, 1(4), 363-384. https://doi.org/10.1504/PIE.2004.005853

Watson, G. H. (1993a). Strategic Benchmarking. New York: John Wiley and Sons.

Watson, G. H. (1993b). The benchmarking workbook-Adapting best practices for performance improvement. Training \& Development, 47(5), 103-103.

Weber, C., Curtis, B., \& Gardiner, T. (2008). Business Process Maturity Model 1.0. Object Management Group. Retrieved from https://www.omg.org/ spec/BPMM/1.0/PDF

Welchman, L. (2015). Managing Chaos: Digital Governance by Design. New York: Rosenfeld Media.

White, D. J., Hubacek, K., Feng, K., Sun, L., \& Meng, B. (2018). The waterenergy-food nexus in East Asia: A tele-connected value chain analysis using inter-regional input-output analysis. Applied Energy, 210, 550-567. https://doi.org/10.1016/j.apenergy.2017.05.159

Willaert, P., Van Den Bergh, J., Willems, J., \& Deschoolmeester, D. (2007). The process-oriented organization: A holistic view developing a framework for business process orientation maturity. Lecture Notes in Computer Science (Including Subseries Lecture Notes in Artificial Intelligence 
and Lecture Notes in Bioinformatics), 4714 LNCS, 1-15. https://doi. org/10.1007/978-3-540-75183-0_1

Williams, S., Pickard, C., Glass, K., \& Glass, A. (2020). Benchmarking water retail cost efficiency in England and Wales. International Journal of the Economics of Business, 431-467. https://doi.org/10.1080/13571516.20 20.1790979

Wudhikarn, R., Chakpitak, N., \& Neubert, G. (2020). Improving the strategic benchmarking of intellectual capital management in logistics service providers. Sustainability (Switzerland), 12(23), 1-23. https://doi. org/10.3390/su122310174

Zagkas, V. K., \& Lyridis, D. V. (2011). A framework for modelling and benchmarking maritime clusters: An application to the maritime cluster of Piraeus. In X. J. Yang, J. M. W. Low \& L. C. Tang (Eds.), Advances in maritime logistics and supply chain systems (pp. 131-156). Singapore: World Scientific Publishing Co. https://doi.org/10.1142/9789814329866_0006

Zairi, M., \& Whymark, J. (2000). The transfer of best practices: How to build a culture of benchmarking and continuous learning - part 2 . Benchmarking: An International Journal, 7(2), 146-167. https://doi. org/10.1108/14635770010326212

Zhang, F. (2020). EMNC technological knowledge flow patterns: An overview of the US patents granted. Multinational Business Review, 28(1), 129155. https://doi.org/10.1108/MBR-03-2019-0021

\section{Internet sources}

Industry 4.0: Building the digital enterprise (2016). PwC. Retrieved 2 February, 2021, from https://www.pwc.com/gx/en/industries/industries-4.0/ landing-page/industry-4.0-building-your-digital-enterprise-april-2016.pdf

Performance Benchmarking in the Water Utilities Sector. The KPI Institute. Retrieved 15 May, 2021, from https://www.performancemagazine.org/ benchmarking-water-utilities-sector/

Polish Waterworks Chamber of Commerce (Izba Gospodarcza Wodociągi Polskie - IGWP). Retrieved 25 May, 2021, from https://www.igwp.org.pl/ index.php/nasza-aktywnosc/benchmarking

Progress on Drinking Water, Sanitation and Hygiene (2017). WHO-UNICEF JMP. Retrieved 5 February, 2021, from https://data.unicef.org/ resources/progress-drinking-water-sanitation-hygiene-2017-updatesdg-baselines/

Strategic Plan IWA 2019-2024, Retrieved 12 December, 2020, from https:// iwa-network.org/wp-content/uploads/2015/12/IWA_StrategicPlan-2019-2024.pdf

Supporting Countries in Unprecedented Times. The World Bank Annual Report 2020. Retrieved 5 August, 2021, from https://www.worldbank. org/en/about/annual-report\#anchor-annual 
Sustainable Development Goals (2015). United Nations Department of Economic and Social Affairs. Retrieves 2 May, 2021, from https://sdgs. un.org/goals

The Connected Enterprise Maturity Model (2016). Rockwell Automation Inc. Retrieved 25 February, 2021, from https://literature.rockwellautomation. com/idc/groups/literature/documents/wp/cie-wp002_-en-p.pdf

The European Federation of National Associations of Water Services (EurEau). Retrieved 25 May, 2021, from https://www.eureau.org/

The International Benchmarking Network for Water and Sanitation utilities (IBNET). Retrieved 5 February, 2021, from https://www.ib-net.org/

Transformation through innovation, ecosystems and sustained outcomes (2021).

PwC. Retrieved 7 June, 2021, from https://www.pwc.com/gx/en/newsroom/analyst-citations/2021/transformation-through-innovation.html

UN World Water Development Report, Wastewater: The Untapped Resource. (2017). UNESCO. Retrieved 5 May, 2021, from https://www.unep.org/ resources/publication/2017-un-world-water-development-reportwastewater-untapped-resource

US EPA Environmental Protection Agency. Redrived 25 May, 2021, from https://www.epa.gov/environmental-topics/water-topics

\begin{abstract}
Abstrakt
CEL: Przeglqd literatury oraz licznych źródeł internetowych, w szczególności platform informacyjnych międzynarodowych organizacji wspierajacych działalność sektora wodnego, miał na celu weryfikację doświadczeń badawczych w zakresie dojrzałości cyfrowej przedsiębiorstw, identyfikację podejść badawczych stosowanych w benchmarkingu wodociqgów, oraz określenie poziomu zainteresowania analizq łańcucha wartości branży wodociqgowej. Stwierdzono, że brak jest metodyki benchmarkingu, która umożliwiłaby obserwację zmian zachodzqcych w procesach biznesowych przedsiębiorstw wodociqgowych pod wpływem technologii cyfrowych. Dlatego w niniejszym artykule przedstawiono ramy do benchmarkingu cyfryzacji procesów biznesowych. W artykule przedstawiono również przesłanki do benchmarkingu cyfryzacji procesów wchodzq̨cych w skład łańcucha wartości przedsiębiorstwa wodociqgowego oraz korzyści płynqce z włączenia technologii cyfrowych wspierajqcych procesy z perspektywy ekonomicznej, społecznej i środowiskowej. Jednym z kluczowych etapów tworzenia koncepcji badań benchmarkingowych jest stworzenie macierzy zmiennych odnoszqcych się do celów realizowanych przez przedsiębiorstwa wodociqgowe. METODYKA: Proponowana koncepcja benchmarkingu cyfryzacji procesów biznesowych wchodzqcych w skład łańcucha wartości przedsiębiorstwa wodociqgowego została przygotowana $w$ oparciu o studia literaturowe oraz analizę wybranych platform internetowych międzynarodowych organizacji działajacych na rzecz sektora wodnego. WYNIKI: Analiza dekompozycji łańcucha wartości przedsiębiorstwa, kryteriów i poziomów oceny dojrzałości procesowej oraz najnowszych technologii cyfrowych pozwoliła na przygotowanie dwóch scenariuszy etapów benchmarkingu procesów oraz wykorzystanie technologii cyfrowych w zależności od poziomu dojrzałości procesowej
\end{abstract}


oraz doświadczeń benchmarkingowych. IMPLIKACJE DLA TEORII I PRAKTYKI: Zaproponowany model jest wysoce koncepcyjny i wymaga walidacji w badaniach pilotażowych w celu weryfikacji poziomów dekompozycji łańcucha wartości, wyboru kluczowych technologii cyfrowych do badań oraz określenia skali dojrzałości cyfrowej dla każdej z uwzględnionych w badaniu technologii. Organizacje prowadzqce badania benchmarkingowe mogq poszerzać zakres swoich badań i dostarczać przedsiębiorstwom wodociqgowym informacje o najnowszych technologiach cyfrowych wspierajacych procesy biznesowe. ORYGINALNOŚĆ I WARTOŚĆ: Wykorzystanie taksonomii łańcucha wartości do oceny wsparcia procesów biznesowych przez technologie cyfrowe jest oryginalnym podejściem. Umożliwia zdobycie wiedzy o znaczeniu technologii cyfrowych we wszystkich procesach realizowanych w przedsiębiorstwie.

Słowa kluczowe: łańcuch wartości, benchmarking procesów, dojrzałość procesowa, dojrzałość cyfrowa, Przemysł 4.0.

\section{Biographical note}

Natalia R. Potoczek (Ph.D., Hab.), Professor at Institute of Economics, Polish Academy of Sciences (INE PAN) in Warsaw. She is a researcher at the Laboratory of Process and Network Analysis at INE PAN, and she works to transfer knowledge between science, business, and the public sphere. She is an Associate Professor at the Wyższa Szkoła Biznesu - National-Louis University. Also, she carries out research and implementation projects. In research and consulting, she combines her knowledge and many years of experience in two areas: business process management and business models.

\section{Conflicts of interest}

The author declares no conflict of interest.

\section{Citation (APA Style)}

Potoczek, N.R. (2021). The use of process benchmarking in the water industry to introduce changes in the digitization of the company's value chain Journal of Entrepreneurship, Management, and Innovation, 17(4), 51-89. https://doi. org/10.7341/20211743 